\title{
Bopopia, a new monotypic genus of Gesneriaceae (Gesnerioideae, Coronanthereae) from New Caledonia
}

\author{
Jérémie MOREL ${ }^{1}$, Jérôme DUMINIL ${ }^{2}$ \& Jérôme MUNZINGER ${ }^{3, *}$ \\ ${ }^{1,3}$ AMAP, Université de Montpellier, IRD, CIRAD, CNRS, INRAE, Montpellier, France. \\ ${ }^{2}$ DIADE, Université de Montpellier, IRD, Montpellier, France. \\ *Corresponding author: jerome.munzinger@ird.fr \\ ${ }^{1}$ Email: morel.jeremie63@gmail.com \\ 2Email: jerome.duminil@ird.fr \\ 1 (1) https://orcid.org/0000-0001-7969-2609 \\ 2 (1) https://orcid.org/0000-0002-2500-824X \\ 3 () https://orcid.org/0000-0001-5300-2702
}

\begin{abstract}
A new genus of Gesneriaceae, Bopopia Munzinger \& J.R.Morel gen. nov., is described from New Caledonia. The genus is based on B. parviflora Munzinger \& J.R.Morel gen. et sp. nov., a new species collected during an expedition on Mt Katalupaik, in the North Province of New Caledonia's main island. Originally considered as a species of Coronanthera, our phylogenetic analysis - including 19 species within Coronanthereae and two individuals of B. parviflora gen. et sp. nov., and using three molecular markers (nuclear rDNA ITS, and chloroplast regions trnL-trnF and $\operatorname{trnE}$-trnT) - showed that the new species is not close to Coronanthera in subtribe Coronantherinae, but belongs to subtribe Negriinae where it is sister to Depanthus. From that genus Bopopia gen. nov. differs in floral symmetry (zygomorphic vs actinomorphic) and the number of stamens (4 vs 5). From the other genera of Negriinae the new genus differs in the white corolla and its indeterminate thyrse with 3 to 5 levels of branching. The morphological circumscription of the subtribe Negriinae is amended to include Bopopia gen. nov. Two keys are provided, one to the subtribes in the tribe Coronanthereae, and one to the genera in subtribe Negriinae. Following the IUCN Red List categories and criteria, the conservation status of B. parviflora gen. et sp. nov. is provisionally assessed as Endangered (EN).
\end{abstract}

Keywords. Gesneriaceae, Gesnerioideae-Coronanthereae-Negriinae, La Planète Revisitée, New Caledonia, Grande Terre, Mt Katalupaik, molecular phylogeny, taxonomy.

Morel J., Duminil J. \& Munzinger J. 2021. Bopopia, a new monotypic genus of Gesneriaceae (Gesnerioideae, Coronanthereae) from New Caledonia. European Journal of Taxonomy 736: 82-101.

https://doi.org/10.5852/ejt.2021.736.1253

\section{Introduction}

New Caledonia is a biodiversity hotspot with an estimated autochthonous flora of 3409 species of flowering plants, of which nearly 75\% are endemic (Morat et al. 2012; Munzinger et al. 2020). Nevertheless, this biodiversity is still poorly known: on average, one new species is described each 
month from the New Caledonian archipelago (Gâteblé et al. 2018). To complete the knowledge of this biodiversity, the research program 'La Planète Revisitée' (http://www.laplaneterevisitee.org/fr) organized several expeditions between 2016 and 2018 in various unexplored and difficult-to-access areas of New Caledonia. In 2017, the southern face of the isolated Mount Katalupaik, a 'no data area' of the archipelago (see map in Birnbaum et al. 2015), was inventoried from 300-900 m altitude. During this expedition, 340 species were collected, 13 being supposedly new to science, nine could be assigned to specimens already present in herbaria, while four were collected for the first time (Munzinger et al. 2018).

One of these potentially new species was a relatively abundant shrub in this locality and is represented by the specimens Bruy et al. 1139 and Munzinger et al. 7980. The plants were flowering at the time of the collection in October. Several characters suggested placement in the family Gesneriaceae Rich. \& Juss. ex DC., including shrubby habit, opposite simple petiolate leaves without stipules, pair-flowered cymes, pentamerous zygomorphic flowers, gamosepalous calyx, gamopetalous corolla, four stamens with connate anthers, presence of hypogynous disk, syncarpous unilocular gynoecium of two carpels, one style, and two stigmas. The new species was initially considered to belong to the genus Coronanthera Vieill. ex C.B.Clarke (Gesnerioideae-Coronanthereae-Coronantherinae; Woo et al. 2011; Weber et al. 2013), because of its shrubby habit, slightly serrate leaves with similar shape and dimensions (blade and petiole), small zygomorphic corolla with four connate stamens, and annular nectary adnate to the ovary.

In order to test the identity of the New Caledonian specimens, and the generic and subtribal position of the species, a molecular phylogenetic study was performed. The combination of molecular and morphological data, consistent with the geographical distribution, confirms that this is a new species and genus. This methodology has been shown to be particularly efficient in the circumscription of genera and species, including the discovery of a considerable number of new genera in the Gesneriaceae (e.g., Araújo et al. 2010; Clark et al. 2010; Wei et al. 2010; Middleton \& Möller 2012).

\section{Material and methods}

\section{Sampling}

Specimens of this new species were collected in the North Province of New Caledonia, on Mt Katalupaik, in October 2017 by David Bruy, Jérôme Munzinger and Marc Pignal. The plants were cut with clippers poles and pressed in the field, then dried at the base camp, notes and photos were taken in the field, and the flowers were preserved in alcohol. Vouchers were deposited at MPU, NOU and P (Appendix 1); acronyms of herbaria follow Index Herbariorum (Thiers continuously updated).

\section{Molecular phylogenetic analysis}

Leaves from the two collections of the new species were dried and preserved in silica gel. DNA was extracted using the mixed alkyltrimethylammonium bromide (MATAB) protocol as described in Scarcelli et al. (2006). DNA quality and quantity were then checked by optical density with the Nanodrop ${ }^{\mathrm{TM}} 8000$ (Thermo Fisher Scientific, Waltham, Massachusetts, United States) and by agarose gel electrophoresis.

The selection of gene regions and analysis methods follows Woo et al. (2011) in order to get results that are directly comparable to their study.

PCR reactions were done in a total volume of $25 \mu \mathrm{l}$ as follows: $12.5 \mu \mathrm{l}$ of QIAGEN Multiplex PCR Master Mix (Qiagen, Germany), $5 \mu 1$ of Qiagen Q-solution, $0.1 \mu 1$ of each primer (forward and reverse) at $10 \mathrm{mM}, 2.5 \mu \mathrm{l}$ DNA template (of ca $15-20 \mathrm{ng} / \mu \mathrm{l}$ ), and water qs $25 \mu \mathrm{l}$. The rDNA ITS region (ITS1, 5.8S gene and ITS2) was amplified using ITS5 and ITS28CC primers (White et al. 1990; Wagstaff \& Garnock-Jones 1998). The intergenic spacer $\operatorname{trn} \mathrm{L}-\operatorname{trn} \mathrm{F}$ was amplified with the $\operatorname{trn} \mathrm{L}-\mathrm{e} / \operatorname{trn} \mathrm{F}$ and the $\operatorname{trn} \mathrm{L}-\mathrm{c} /$ 
trnL-d primers (Taberlet et al. 1991). The intergenic spacer $\operatorname{trn} \mathrm{E}-\operatorname{trn} \mathrm{T}$ was amplified with the $\operatorname{trn} \mathrm{E} / \operatorname{trn} \mathrm{Tr}$ primers (Doyle et al. 1992). PCR were done on an Applied Biosystems ${ }^{\circledR}$ Veriti ${ }^{\circledR}$ 96-Well thermal cycler (Applied Biosystems, Foster City, USA) with an activation step of $95^{\circ} \mathrm{C}$ for $15 \mathrm{~min}$, followed by 38 cycles of $94^{\circ} \mathrm{C}$ denaturation for $30 \mathrm{~s}, 50^{\circ} \mathrm{C}$ for $30 \mathrm{~s}$ for annealing, $72^{\circ} \mathrm{C}$ for $2 \mathrm{~min}$ of extension, and a final extension phase at $72^{\circ} \mathrm{C}$ for $10 \mathrm{~min}$.

Sanger sequencing (Sanger et al. 1977) was performed by GENEWIZ® (Leipzig, Germany) with Dye Terminator Big Dye ver. 3.1 (Life Technologies/Thermofisher). DNA sequencing reactions were purified using in-house beads (magnetic bead-based) before being charged on an ABI $3730 \mathrm{XL}$ DNA analyzer (Life Technologies/Thermofisher). Base calling was done using KBAnalysis (KB basecaller ver. 1.4.1). Reverse and forward reads were assembled using CodonCode Aligner ver. 8.0.2 (https://www.codoncode.com).

In order to determine the taxonomic coverage to be included in our phylogenetic analysis, we evaluated the taxonomic proximity of our DNA sequences using blastn suite (NCBI) and relying on the query coverage and the percentage of identity. For ITS, the closest taxa to the new species were Lenbrassia australiana var. glabrescens B.Morley (query coverage: 81\%; percent identity: 95.4\%), Lenbrassia australiana var. australiana (C.T.White) G.W.Gillett (81\%; 95.1\%) and Depanthus glaber S.Moore $(81 \%$; 95.1\%). The $\operatorname{trn} \mathrm{L}-\operatorname{trn} \mathrm{F}$ sequence was closest to Lenbrassia australiana var. australiana $(99 \%$; 99.8\%), Sarmienta scandens Pers. (99\%; 98.7\%) and Negria rhabdothamnoides F.Muell. (91\%; $100 \%$ ). The trnE-trn T was closest to Lenbrassia australiana var. australiana (98\%; 98\%), Negria rhabdothamnoides (98\%; 97.9\%) and Depanthus glaber (98\%; 97.8\%).

All these taxa are included in the tribe Coronanthereae Fritsch. Thus, the sequence matrix of Woo et al. (2011), covering the Southeast Pacific Gesneriaceae, was reduced to 35 samples corresponding to an exhaustive sampling of Coronanthereae genera. Sequences produced subsequently to Woo's work were also included in the matrix, from Coronanthera (Serrano-Serrano et al. 2017) and from Negria F.Muell (Perret et al. 2013). All GenBank sequence accessions and their corresponding vouchers can be found in Appendix 1.

Two members of the tribe Beslerieae Bartl. were selected as outgroups based on phylogenetic relationships shown in Woo et al. (2011): Gasteranthus atratus Wiehler from Ecuador and Cremosperma castroanum C.V.Morton from Peru. The 39 sequences were first aligned using MAFFT under default parameters (Katoh et al. 2017) and corrected manually to minimize substitutions and indels by eventbased criteria in order to constitute homology hypotheses (Morrison 2006). Then, we used GBlocks $0.91 \mathrm{~b}$ (Castresana 2000) on each ITS, $\operatorname{trn} \mathrm{L}-\mathrm{t} r n \mathrm{~F}$ and $\operatorname{trn} \mathrm{E}-\mathrm{trn} \mathrm{T}$ alignments. GBlocks deletes segments of contiguous non-conserved positions, gap positions and non-conserved flanking positions. It has consequently proven very useful in increasing phylogenetic accuracy (e.g., Roalson \& Roberts 2016). For ITS alignment, we used the default stringent parameters, disallowing smaller final blocks, gap positions and non-conserved flanking positions. Less stringent parameters were used (allowing gap position within the final blocks and less strict flanking positions) for $\operatorname{trn} \mathrm{L}-\operatorname{trn} \mathrm{F}$ and $\operatorname{trn} \mathrm{E}-\operatorname{trn} \mathrm{T}$. The characteristics of the different DNA sequences are given in Table 1.

We analyzed the cpDNA and ITS independently (not shown) in order to assess whether or not the data could be concatenated. We used the model GTR $+\mathrm{I}+\Gamma$ for maximum likelihood (ML) analysis and the following models for Bayesian inference (BI) analysis: SYM $+\Gamma$ for ITS, GTR + I for $\operatorname{trn} \mathrm{L}-\operatorname{trn} \mathrm{F}$ and GTR $+\mathrm{I}+\Gamma$ for $\operatorname{trn} \mathrm{E}-\operatorname{trn} \mathrm{T}$. The partition-homogeneity test (Farris et al. 1994) as implemented in PAUP* ver. 4.0a (Swofford 2002) was performed with 10000 bootstrap replicates and did not find significant differences between any partitions $(p=0.8487)$. Therefore, a combined analysis of the DNA regions could be performed. 
Table 1. Nucleotide sequence characteristics of the gene regions analysed.

\begin{tabular}{lccccc}
\hline & No. sequences & $\begin{array}{c}\text { Length } \\
\text { range (bp) }\end{array}$ & $\begin{array}{c}\text { Aligned } \\
\text { length (bp) }\end{array}$ & $\begin{array}{c}\text { Fraction retained by } \\
\text { GBlocks (\%) }\end{array}$ & $\begin{array}{c}\text { Final length of } \\
\text { alignment (bp) }\end{array}$ \\
\hline $\begin{array}{l}\text { ITS } \\
\text { trnL-trnF }\end{array}$ & 39 & $613-639$ & 675 & $82 \%$ & 554 \\
spacer \\
$\begin{array}{l}\text { trnE-trnT } \\
\text { spacer }\end{array}$
\end{tabular}

The research of the optimal substitution model was performed with PartitionFinder2 (Lanfear et al. 2016) using the Akaike Information Criterion (AIC; Posada \& Buckley 2004). ML analysis was run on the partitioned data set in RaxML ver. 8 (Stamatakis 2014) with 100 bootstrap replicates. BI analysis was run in Mrbayes ver. 3.2.7 (Ronquist et al. 2012). All the parameters values were unlinked across partitions and estimated during the Markov chain Monte Carlo (MCMC) runs. Two independent analyses, starting from different random trees, were run, each with four Markov chains (one cold chain and three incrementally heated chains). Independent analyses were conducted with 5000000 generations each, with a sampling frequency of 1 tree every 1000 generations. Convergence between the two independent runs was checked using Tracer ver. 1.7.1 (Suchard et al. 2018). We discarded the first $25 \%$ of the trees as burn-in, and the retained ones were summarized in a majority rules consensus tree (Fig. 1).

\section{Specimens examined and morphology}

After confirmation that the collected species was indeed a member of Gesneriaceae, we examined all collections within this family from Oceania and Asia present in MPU, NOU and P, as well as all specimens without family identification from the same areas in these herbaria. In addition, we used virtual collections: Global Plant initiative (https://plants.jstor.org/), e-ReColNat infrastructure (https://www.recolnat.org/fr/), and Z herbarium (https://www.herbarien.uzh.ch/en/belegsuche.html).

Morphological descriptions were prepared using standard terminology (Harris \& Harris 2001). Vegetative parts were measured directly on herbarium specimens. Details of androecium and gynoecium were measured in flowers preserved in alcohol (part of the collection Munzinger et al. 7980). The measurements are given as follows: (minimum) first quartile-third quartile (maximum) (following Munzinger et al. 2016). For the remaining measurements with fewer observations, we chose to only give the minimum and maximum values observed. The drawings of the new species are based on photographs taken in the field and of specimen parts preserved in alcohol. We applied the IUCN Red List categories and criteria (IUCN 2019) to propose a conservation assessment of the species.

\section{Abbreviations used in figures 2, 4 and 6}

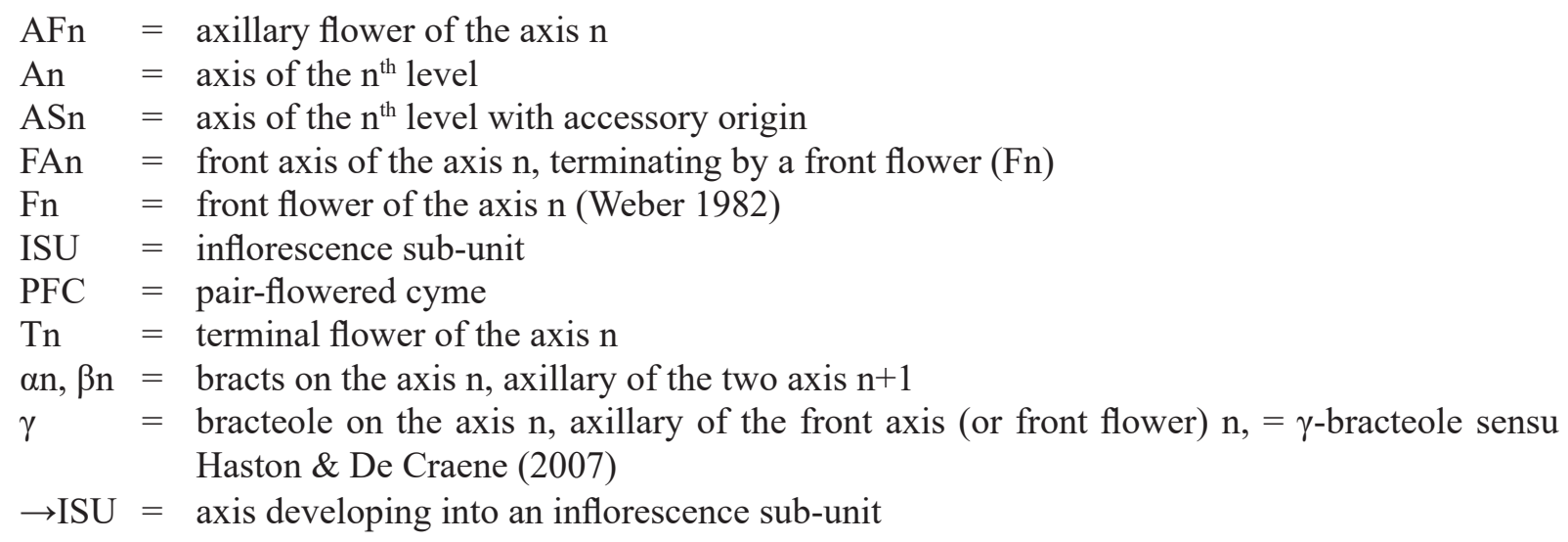




\section{Results}

\section{Molecular phylogenetic analysis}

Fig. 1 shows the 50\% majority-rule consensus tree obtained with the Bayesian analysis. The maximum likelihood tree has the same topology, aside from two nodes which were not supported $(<60 \%$ bootstrap value).

Subtribe Negriinae is strongly supported with a posterior probability (PP) value of 1 and a bootstrap value (BS) of 100. The separation between subtribes Coronantherinae Fritsch and Mitrariinae Hanst. is supported with a PP value of 0.9 and a BS value of 66 . Monophyly for all genera represented by two or more species is strongly supported $(\mathrm{PP}=1 ; \mathrm{BS}=100)$.

The new species is supported as a member of subtribe Negriinae $(\mathrm{PP}=1 ; \mathrm{BS}=100)$ and as sister to the genus Depanthus $\mathrm{S}$. Moore $(\mathrm{PP}=0.8 ; \mathrm{BS}=81)$.

\section{Herbarium study}

We found that this taxon had never been collected before.

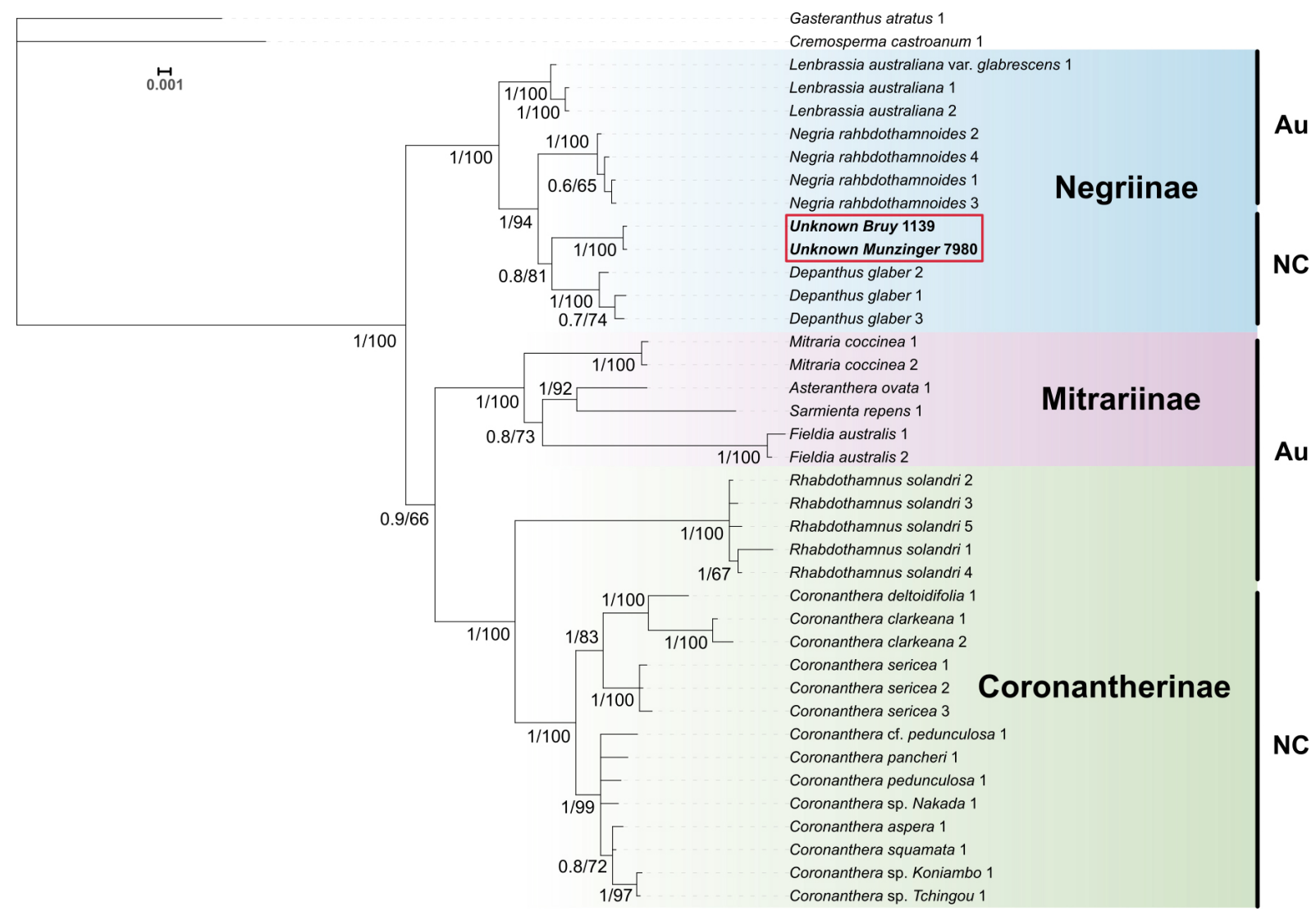

Fig. 1. 50\% Bayesian majority-rule consensus cladogram based on combined markers. Numbers indicating clade support: left of slash $=$ Bayesian posterior probability value; right of slash $=$ maximum likelihood bootstrap value. $\mathrm{Au}=$ Australia; $\mathrm{NC}=\mathrm{New}$ Caledonia. 


\title{
Key to the subtribes in the tribe Coronanthereae
}

1. Epiphytic creepers and subshrubs to $1 \mathrm{~m}$ tall; leaves small, $0.5-4 \mathrm{~cm}$ long; inflorescence axillary, solitary; stamens 2-4; fruit an indehiscent berry subtribe MitrariinaeHanst.

- Tree to shrubs $>2 \mathrm{~m}$ tall; leaves small to large, 2-25 cm long; inflorescence an axillary cyme or indeterminate thyrse (Fig. 2), or flower solitary; stamens 4-5; fruit a dry capsule or an indehiscent berry (unknown in Bopopia gen. nov.)

2. Trees and shrubs, $2-15 \mathrm{~m}$ tall; leaves toothed or weakly toothed, small to large, $2-25 \mathrm{~cm}$ long; inflorescence an axillary cyme, peduncle short, generally 3-8-flowered, or flower solitary (Rhabdothamnus A.Cunn.); flowers zygomorphic; stamens 4, staminode 1, anthers coherent, in coronal formation; fruit an ovoid dry capsule, four-valved, valves apically coherent, dehiscing by basal slits, septicidally then loculicidally subtribe Coronantherinae Fritsch

- Trees, 6-13 m tall; leaves entire or toothed, large, 5-20 cm long; inflorescence an axillary cyme, peduncle short to long, 1-3-flowered or an indeterminate thyrse with 3-5 levels of branching (Bopopia gen. nov.); flowers zygomorphic or actinomorphic; stamens 4-5, anthers free or coherent; fruits beaked, fleshy, and indehiscent, or dry, woody, two-valved, apically septicidally dehiscent, or four-valved, dehiscing septicidally plus loculicidally (unknown in Bopopia gen. nov.) subtribe Negriinae V.L.Woo, J.F.Smith \& Garn.-Jones

\section{Key to the genera in the subtribe Negriinae}

1. Inflorescence an indeterminate thyrse with 3-5 levels of branching (Fig. 2) (New Caledonia) Bopopia Munzinger \& J.R.Morel gen. nov.

- Inflorescence a cyme 1-3-flowered, or solitary flower (Australia or New Caledonia) 2

2. Fruit a berry (NE Australia) Lenbrassia G.W.Gillett

- Fruit a capsule 3

3. Corolla actinomorphic, stamens 5, capsule dehiscing septicidally by 2 valves (New Caledonia) ...... Depanthus S.Moore

- Corolla zygomorphic, stamens 4, capsule dehiscing septicidally plus loculicidally by 4 valves (Australia: Lord Howe Island) Negria F.Muell.

\section{Taxonomic treatment}

\author{
Class Magnoliopsida Brongn. \\ Order Lamiales Bromhead \\ Family Gesneriaceae Rich. \& Juss. ex DC. \\ Subfamily Gesnerioideae Burnett \\ Tribe Coronanthereae Fritsch
}

Subtribe Negriinae V.L.Woo, J.F.Smith \& Garn.-Jones

\section{Emended diagnosis}

To include Bopopia gen. nov., the diagnosis of the subtribe Negriinae is modified as follows:

Trees, 6-13 m tall; leaves glabrous or pubescent, entire or toothed, lanceolate to ovate, elliptic to obovate, $5-20 \mathrm{~cm}$ long $\times 2.5-11 \mathrm{~cm}$ wide; inflorescence an axillary cyme, peduncle short $(0.5-1.5$ $\mathrm{cm})$ to long (3-14 cm), 1-3-flowered or an indeterminate thyrse with 3-5 levels of branching; flowers zygomorphic or actinomorphic, white, yellow or orange in color; stamens 4-5, anthers free or coherent; fruits (unknown in Bopopia gen. nov.) beaked, fleshy, and indehiscent, or dry, woody, two-valved, apically septicidally dehiscent, or four-valved, dehiscing septicidally plus loculicidally. Seeds (unknown 
in Bopopia gen. nov.) subglobose to elliptic, striated, 0.7-0.9 $\mathrm{mm}$ long, numerous; pollen spheroidal to mildly prolate in shape, $12-22 \mu \mathrm{m}$ in diameter.

\section{Genera included}

Depanthus, Bopopia gen. nov., Lenbrassia, Negria.

Genus Bopopia Munzinger \& J.R.Morel gen. nov.

\section{Type species} urn:lsid:ipni.org:names:77215492-1

Bopopia parviflora Munzinger \& J.R.Morel gen. et sp. nov., by present designation.

\section{Diagnosis}

Bopopia gen. nov. differs from other genera of Coronanthereae in its inflorescence: an axillary indeterminate thyrse with ultimate axes being pair-flowered cymes and inferior axes being indeterminate thyrses with three to five levels of branching (vs 3-flowered cymes or solitary flowers); it differs from Depanthus in floral symmetry (zygomorphy vs actinomorphy), stamen number (4 vs 5); from Negria in inserted (vs exserted) stamens, and connate (vs free) anthers; from Lenbrassia in bilobed (vs spatulate) stigma.

\section{Etymology}

The genus is named after the land and people of Bopope (Pwöpwöp), in the vicinity of Mt Katalupaik.

Bopopia parviflora Munzinger \& J.R.Morel gen. et sp. nov. urn:lsid:ipni.org:names:77215493-1

Figs $2-7$

\section{Diagnosis}

Bopopia parviflora gen. et sp. nov. is similar to Coronanthera clarkeana Schltr., C. deltoidifolia Vieill. ex C.B.Clarke, C. pinguior C.B.Clarke and Depanthus glaber in its glabrous adaxial leaf surface but differs in its unique inflorescence structure within the tribe and also vegetatively in leaf measurements, blade, apex and base shape, margin (entire vs serrate), and abaxial indumentum, as well as petiole length and indumentum (Table 2).

\section{Etymology}

The specific epithet refers to the small flowers as compared to other Gesneriaceae known from New Caledonia.

\section{Type}

NEW CALEDONIA - North Province, Bopope, southern slope of Mount "Kantalupaik" [Katalupaik]; $20^{\circ} 50^{\prime} 27^{\prime \prime} \mathrm{S}, 165^{\circ} 0^{\prime} 38^{\prime \prime} \mathrm{E}$; alt. 500 m; 29 Oct. 2017; fl.; J. Munzinger, D. Bruy \& M. Pignal 7980; holotype: P[P01073391]; isotypes: G, MO, MPU[MPU312888][MPU312889], NOU[NOU090953], $\mathrm{P}[\mathrm{P} 00865080], \mathrm{W}$.

\section{Paratype}

NEW CALEDONIA • North Province, Bopope, southern slope of Mount "Kantalupaik" [Katalupaik]; $20^{\circ} 50^{\prime} 28^{\prime \prime} \mathrm{S}, 165^{\circ} 0^{\prime} 38^{\prime \prime}$ E; alt. 500 m; 29 Oct. 2017; fl.; D. Bruy, J. Munzinger, \& M. Pignal 1139; K, MO, MPU[MPU311450][MPU312887], NOU[NOU090952], P[P01073272]. 


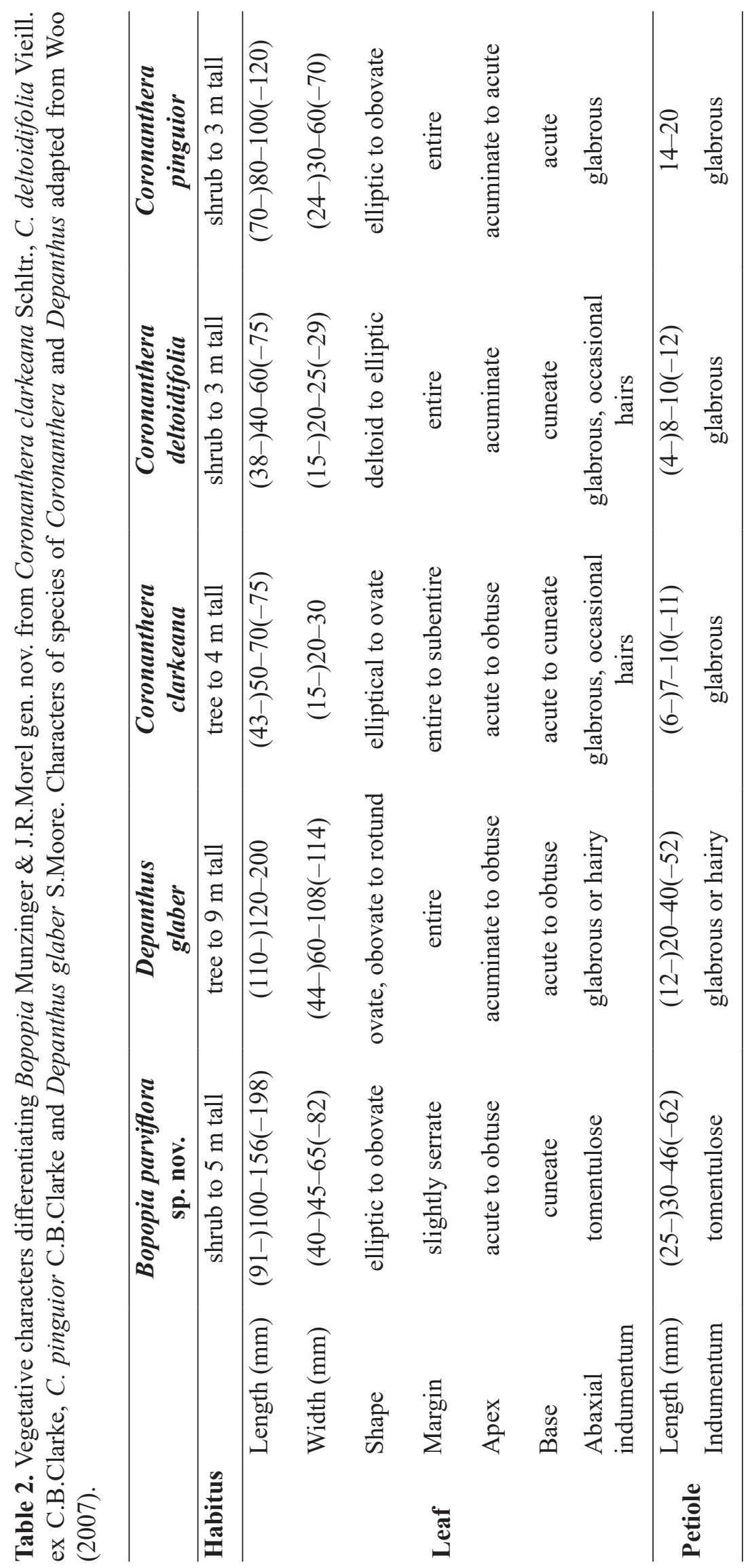




\section{Description}

Shrub up to $5 \mathrm{~m}$ tall, rarely branched. Twigs all orthotropous (Fig. 3A) green to red (Fig. 3B), angular and tomentulose, simple pluricellular trichomes appressed toward the apex, terminal vegetative bud densely tomentulose. Leaves opposite and decussate; clustered at the top of branches (Fig. 3A); blade $(9.1-) 10-15.6(-19.8) \times(4-) 4.5-6.5(-8.2) \mathrm{cm}$, elliptic to obovate, dark green above (Fig. 3C, E), pale green below (in vivo; Fig. 3G), glabrous adaxially, tomentulose abaxially, base cuneate, apex acute to obtuse, margin slightly serrate, lateral veins $(3-) 4(-5)$ per side. Petiole yellow (in vivo; Fig. 3B, G), (25-)30-46(-62) $\mathrm{mm}$ long, (1-)1.6-2.2(-2.7) $\mathrm{mm}$ wide, tomentulose. Inflorescence axillary, indeterminate thyrse, with ultimate axes being pair-flowered cymes (Fig. 4), and inferior axes being indeterminate thyrses; three to five levels of branching (Figs 2, 3B), axes tomentulose, (12-)15-32(-38) flowers per inflorescence, with peduncle/first axis (17-)32-61(-72) $\mathrm{mm}$ long, (0.5-)0.8-1.2(-1.3) $\mathrm{mm}$ wide, tomentulose. Second axis 10-23(-32) mm long, 0.3-0.7(-1) $\mathrm{mm}$ wide, bracteoles linear, (2.5-)3-4.2(-4.5) $\mathrm{mm}$ long; third axis 3-11(-14) $\mathrm{mm}$ long, (0.2-)0.3-0.5(-0.6) $\mathrm{mm}$ wide, bracteoles linear, (1.5-)1.9-2.6(-2.8) $\mathrm{mm}$ long, pedicels $1.5-6.5 \mathrm{~mm}$ long. Calyx with 5 equal lobes, sepals broadly triangular, (1.2-) 1.4-1.8(-2) $\mathrm{mm}$ long, $0.4-0.5 \mathrm{~mm}$ wide at base, slightly connate at the base and attenuate at apex (Figs 3F, 5B-C), tomentulose outside and glabrous inside (Fig. 5C), the lobes not exceeding $25 \%$ of the total length of the calyx (Fig. 3F, 5B-C). Corolla zygomorphic, uniformly white, shortly ventricose, tube curved, (2.2-)2.6-3.6(-4.1) mm long, limb of five inequal oval to orbicular lobes, rounded, strongly curled outwards, the median lobe ca $1.5 \times 1.3 \mathrm{~mm}$, the two lateral lobes ca 1.0 $\times 1.0 \mathrm{~mm}$, the two dorsal lobes ca $0.5 \times 0.6 \mathrm{~mm}$; outer surface of corolla tomentulose, inner surface of corolla glabrous (Fig. 5D). Androecium, four stamens, inserted, alternating with corolla lobes, subequal (Fig. 5D); filaments broad, $0.1 \mathrm{~mm}$ in diameter, flattened near the base, glabrous, adnate to the base of the corolla tube for 1-2 mm (Fig. 5D); four anthers connate, flat, irregularly cordiform (Fig. 5D-E),

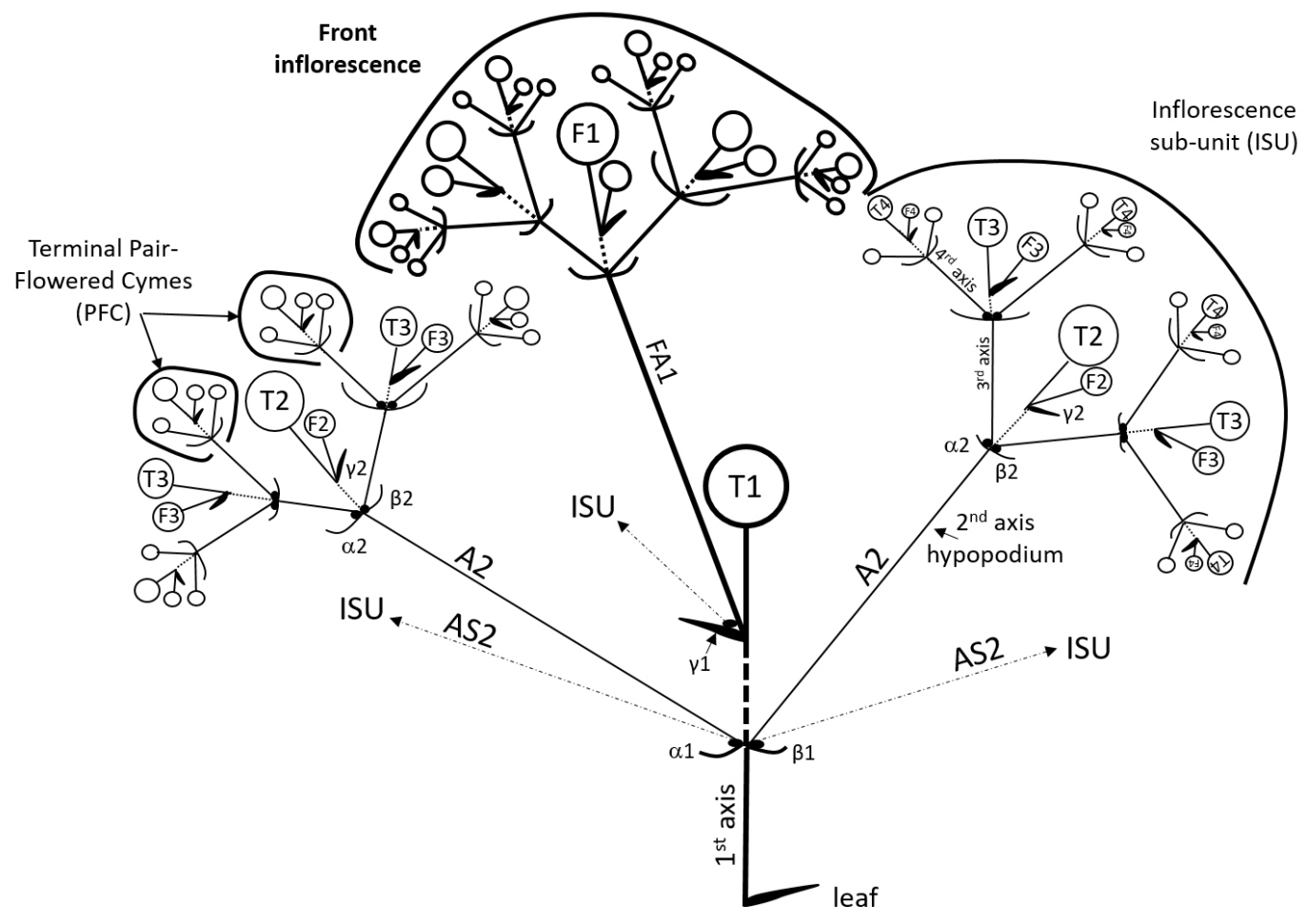

Fig. 2. Schema of the inflorescence of Bopopia parviflora Munzinger \& J.R.Morel gen. et sp. nov., an indeterminate thyrse. Only four axes are represented on this schema (while up to 5 were seen on herbarium specimens). 


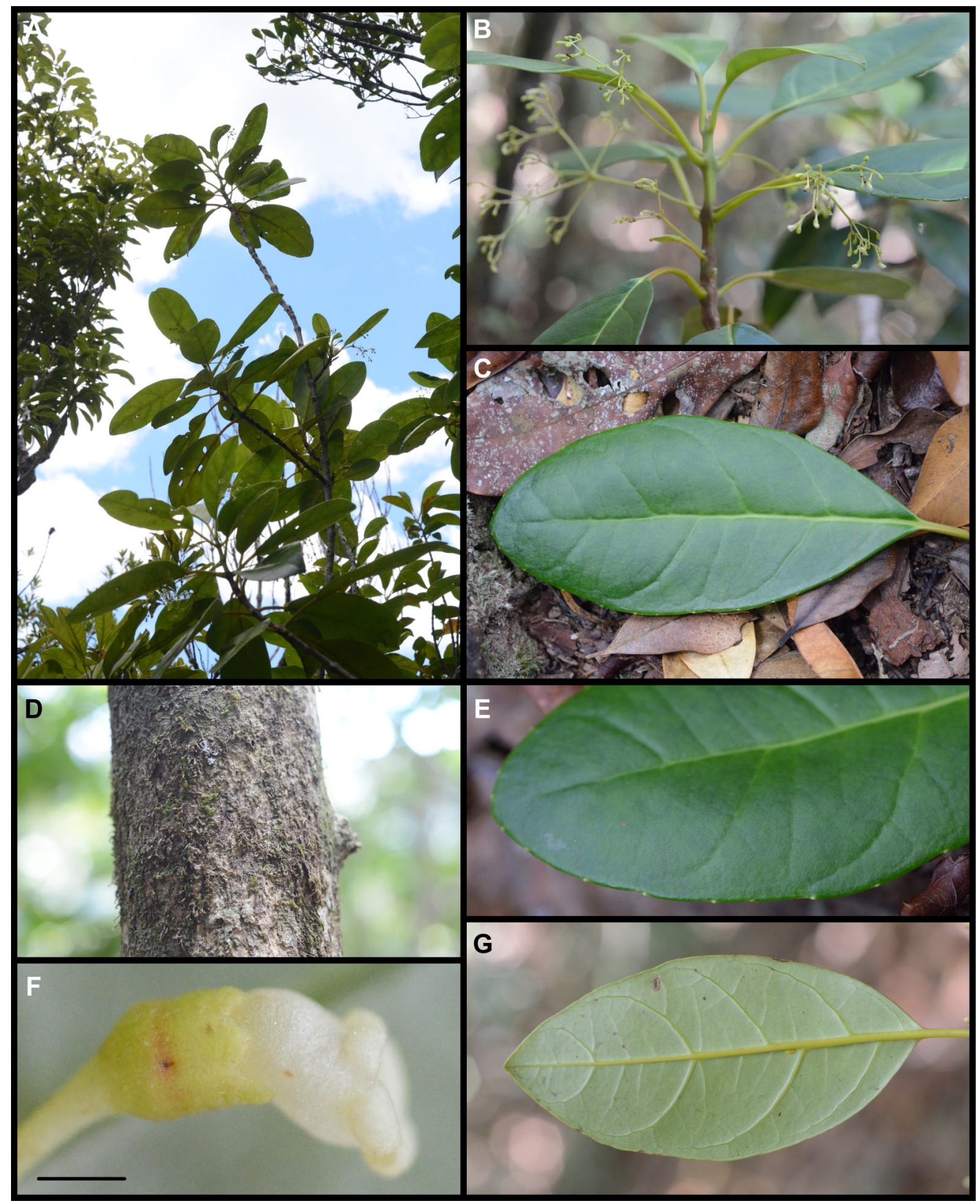

Fig. 3. Bopopia parviflora Munzinger \& J.R.Morel gen. et sp. nov. A. Habit. B. Upper part of stem and axillary inflorescences C. Adaxial side of leaf. D. Trunk. E. Magnified leaf showing leaf teeth (or hydathodes?). F. Flower in lateral view. G. Abaxial side of leaf. Scale bar: $F=1 \mathrm{~mm}$. Photographs taken by Jérôme Munzinger. 
pollen spheroidal, 11-14 $\mu \mathrm{m}$. Nectary ring-shaped, ca $0.25 \mathrm{~mm}$ thick, continuous or with shallow lobes at the rim, pinkish (preserved in alcohol), adnate at the base of the ovary (Fig. 5C). Gynoecium ovoid, ca $1 \times 1 \mathrm{~mm}$, pubescent, bicarpellate, bilocular, style short, ca $0.15 \mathrm{~mm}$ long, ca $0.4 \mathrm{~mm}$ wide, stigma bilobed (Fig. 5C); ovules numerous (ca 50), ellipsoid, 100-130 $\mu \mathrm{m}$ long. Fruit unknown.

\section{Distribution}

The new species is presently only known from the North Province of New Caledonia's main island Grande Terre, on the south flank of Mt Katalupaik, around $500 \mathrm{~m}$ a.s.l. (Fig. 7), about $17 \mathrm{~km}$ as the crow flies south of Hienghène.

\section{Habitat and ecology}

The plants occur in dense humid forests from low to medium elevations on volcano-sedimentary substrates (Jaffré et al. 2012). Collecting points projected on the geological map (Gouvernement de la NouvelleCalédonie 2019) fall in a wide area of black siltites surrounded by basalts, dolerites, undifferentiated gabbros or fine tuffs. They are quite far from serpentine veins (ultramafic) in that area; thus the species is considered to grow on non-ultramafic substrates. Individuals of B. parviflora gen. et sp. nov. were observed to be relatively abundant in the valley that was explored ( $\sim 100 \mathrm{~m}$ wide). Additional surveys are needed in the surrounding valleys.

\section{Phenology}

Plants collected in flower in October 2017. The length of the flowering time and the period of fructification are currently unknown.

\section{Conservation status}

Bopopia parviflora gen. et sp. nov. is only known from one population corresponding to a single location sensu IUCN (2019), and was estimated to contain $<250$ individuals. This population is not in a protected area. The forest on the southern flank of Mt Katalupaik is highly fragmented by fire (Fig. 7), and fire appears to be a recurrent threat. The conservation status of the species is therefore preliminarily assessed as Endangered [EN: D]. This assessment has been submitted to the New Caledonian Plant Red List Authority for review and validation.

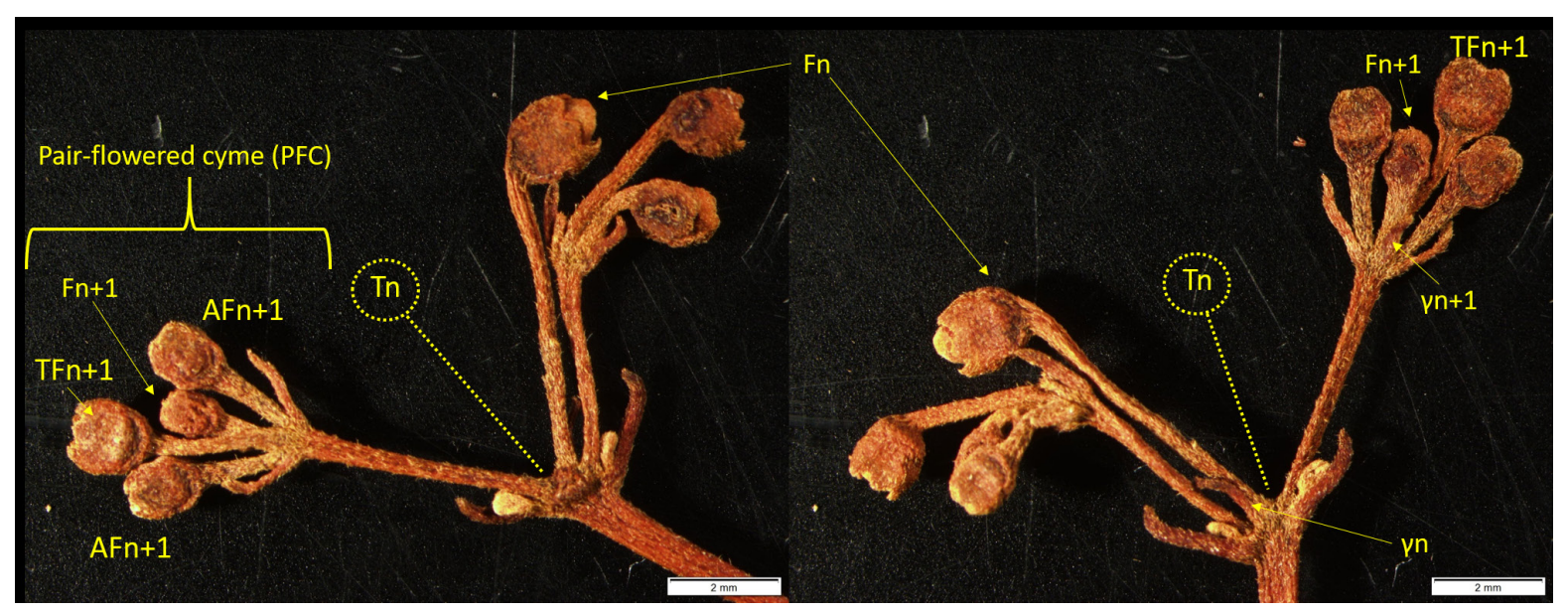

Fig. 4. Recto and verso photographs of an ultimate inflorescence axis of Bopopia parviflora Munzinger \& J.R.Morel gen. et sp. nov., showing the pair-flowered cyme. 


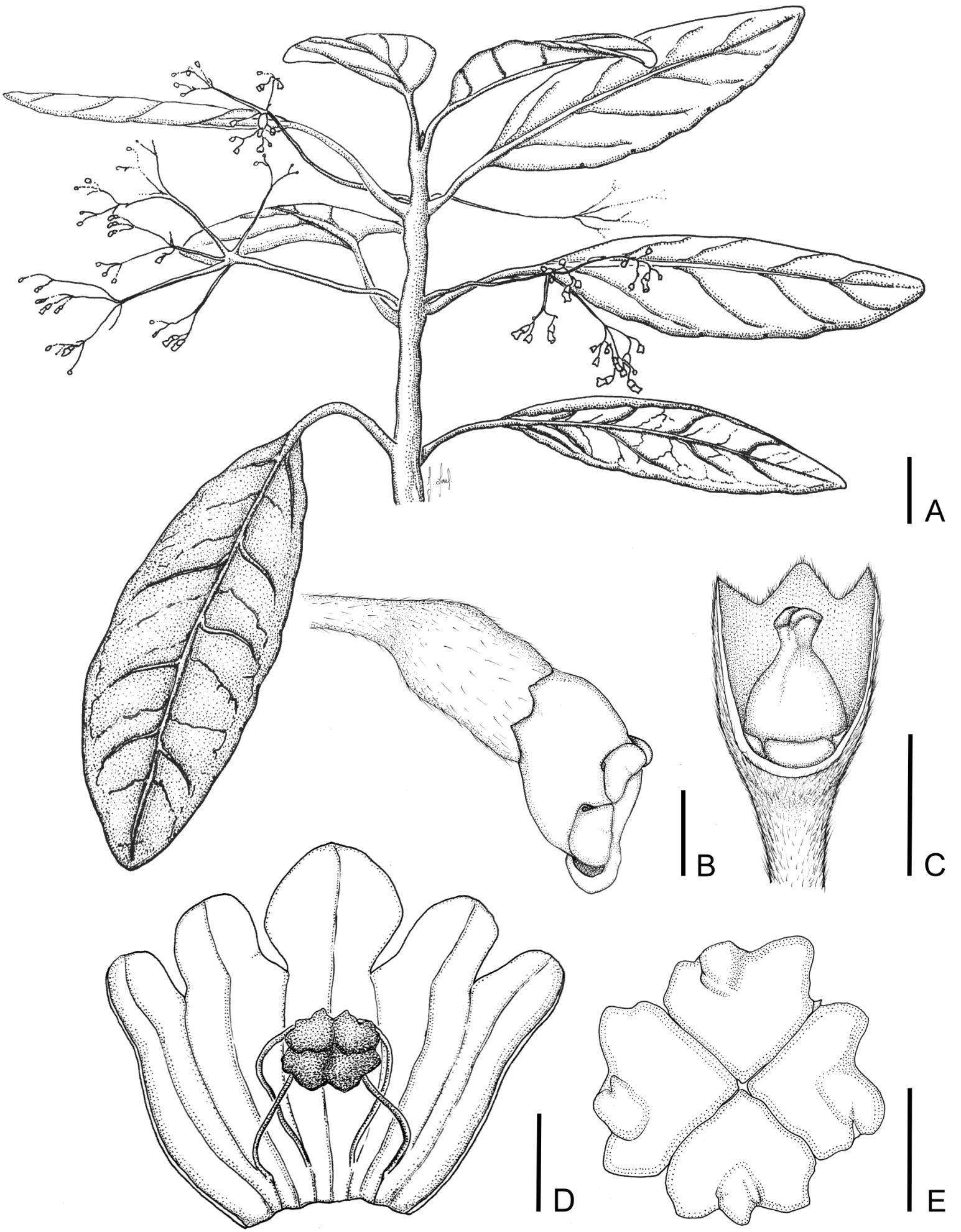

Fig. 5. Bopopia parviflora Munzinger \& J.R.Morel gen. et sp. nov. A. Part of plant showing opposite leaves and axillary inflorescences. B. Flower in lateral view. C. Calyx cut open to show the gynoecium. D. Longitudinal section of corolla, showing stamens (lobes unrolled). E. Top view of connate anthers. Scale bars: A $=20 \mathrm{~mm} ; \mathrm{B}-\mathrm{D}=1 \mathrm{~mm} ; \mathrm{E}=0.4 \mathrm{~mm}$. Drawn from photographs taken by Jérôme Munzinger and parts of the specimen Munzinger et al. 7980 preserved in alcohol. 


\section{Discussion}

Gesneriaceae are a family in the order Lamiales and comprise ca 150 genera and over 3400 species worldwide (Perret et al. 2013; Woo et al. 2011; Weber et al. 2013). In New Caledonia, this family is represented by the genera Cyrtandra J.R.Forst. \& G.Forst (Didymocarpoideae-Trichosporeae), Coronanthera, and Depanthus (Gesnerioideae-Coronanthereae). Cyrtandra comprises more than 650 species (Atkins et al. 2013), although only a single species is found in New Caledonia, Cyrtandra mareensis Däniker, which is endemic to Maré Island (Morat et al. 2001; Cronk et al. 2005). Coronanthera and Depanthus are part of the tribe Coronanthereae that comprises nine genera in total (Woo 2007; Woo et al. 2011; Weber et al. 2013). Depanthus is a genus endemic to New Caledonia, with two described species, D. glaber and D. pubescens Guillaumin, although Woo (2007) considers these species to be synonymous in his $\mathrm{PhD}$ thesis (not validly published). All known species of Coronanthera are found in the archipelago of New Caledonia except Coronanthera grandis G.W.Gillett, an endemic of the Solomon Islands (Bougainville and Ysabel islands; Gillett 1967). Woo et al. (2011) published a phylogenetic study of Coronanthereae based on nuclear (ITS) and chloroplast ( $t r \mathrm{~L}$-trnF and $\operatorname{trn} \mathrm{E}-\operatorname{trn} \mathrm{T}$ ) sequences. This study confirmed the monophyly of the tribe that can be subdivided into three subtribes: Coronantherinae Fritsch, Mitrariinae Hanst., and Negriinae V.L.Woo, J.F.Smith \& Garn.-Jones. Furthermore, it showed that Coronanthera and Depanthus fall into different subtribes, Coronantherinae and Negriinae, respectively. Ancestral-area reconstruction and molecular dating of the subtribes supported multiple migrations from New Caledonia based on long-distance dispersal events in the Miocene (Woo et al. 2011): two migrations of Negriinae to Queensland (Lenbrassia) and Lord Howe Island (Negria), one migration of Coronantherinae to New Zealand (Rabdothamnus), and a potential (untested) migration to Solomon islands (Coronanthera).

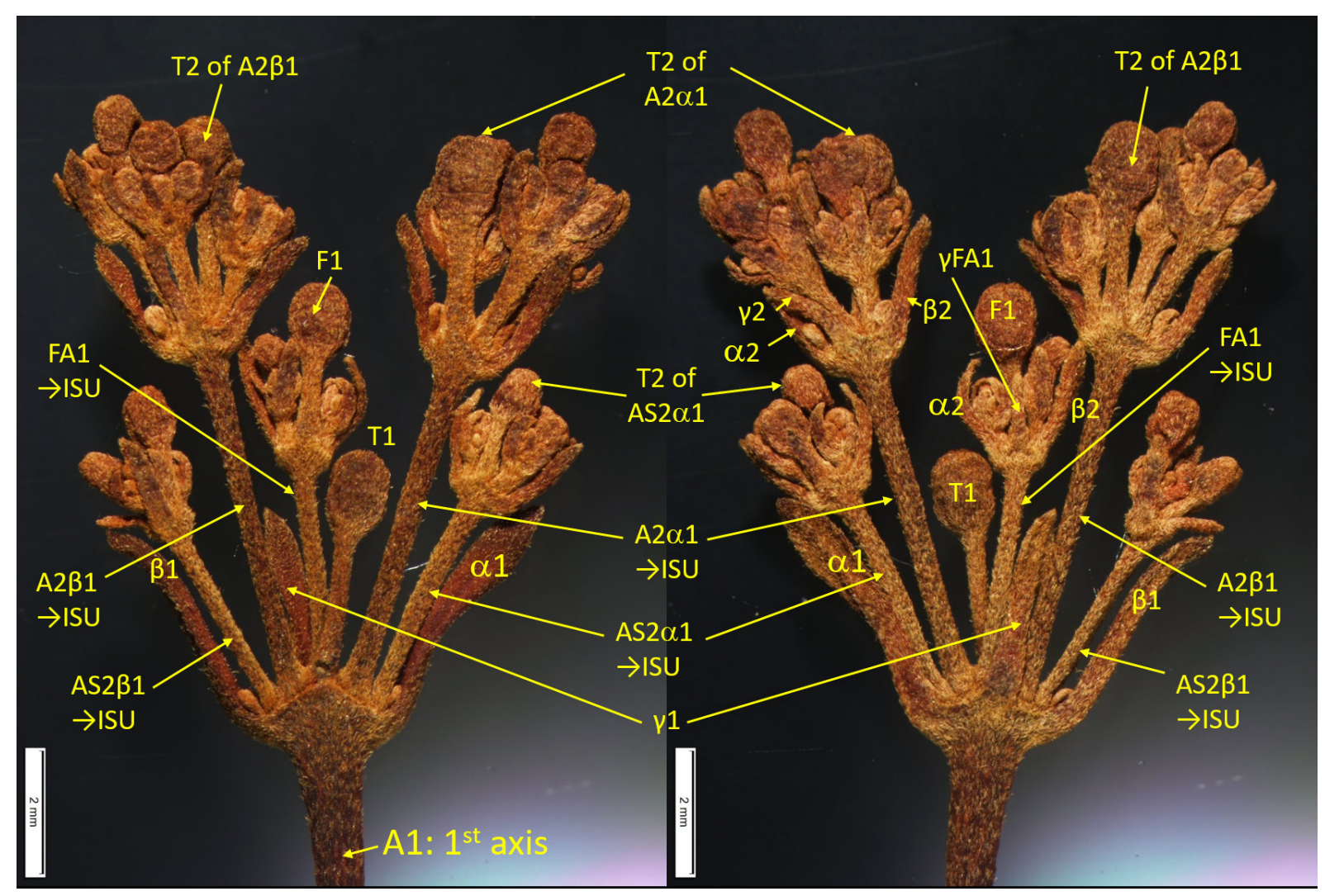

Fig. 6. Recto and verso photographs of a very young inflorescence of Bopopia parviflora Munzinger \& J.R.Morel gen. et sp. nov. 
Herbaria are a major frontier for species discovery (Bebber et al. 2010), and indeed Woo (2007) listed nine new species of Coronanthera, based on herbaria collections, in need of formal description. Several of these were collected a long time ago and are still waiting for the attention of a taxonomic specialist. An examination of all New Caledonian Gesneriaceae in major herbaria showed that the species described here as Bopopia parviflora gen. et sp. nov. was never collected before. Thus field expeditions, such as 'La Planète Revisitée', are still very important to complete the inventory of New Caledonia's flora.

The molecular data place the new species into tribe Coronanthereae, but surprisingly, not in Coronanthera and subtribe Coronantherinae, but in subtribe Negriinae, here being the sister taxon to the genus Depanthus (Fig. 1). It is important to note that the placement of the new species as sister to Depanthus is only weakly $(\mathrm{PP}=0.8)$ to moderately $(\mathrm{BS}=81)$ supported. Consequently, additional taxon sampling and/or inclusion of additional loci (particularly nuclear) is warranted. Morphologically, the cyme structure is in general agreement with Gesneriaceae, with ultimate axes ending by pair-flowered cymes (PFC) (Weber 1982, 1995) as illustrated in Fig. 4. But, in Gesneriaceae, the front flower generally

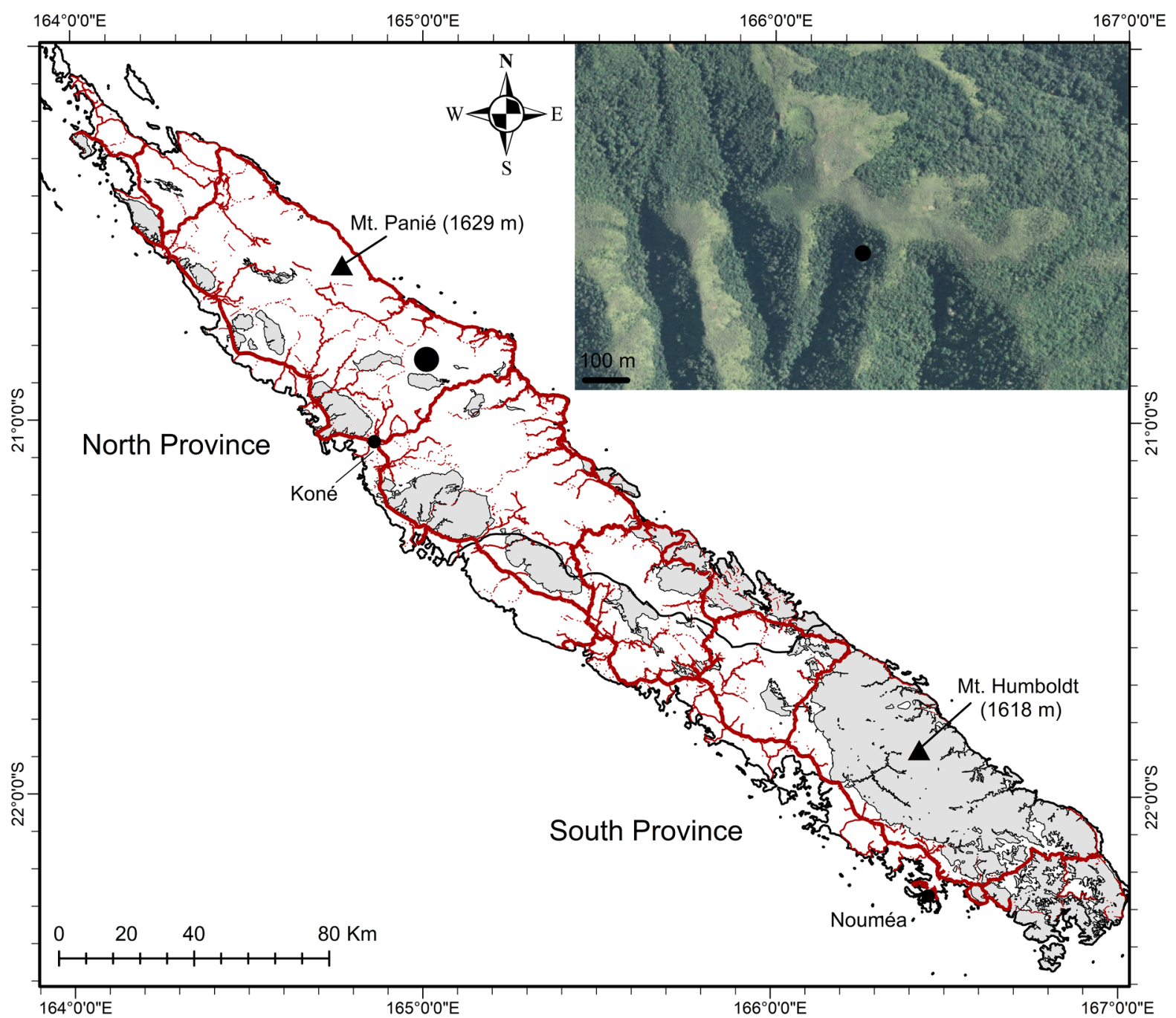

Fig. 7. Map of New Caledonia's main island, Grande Terre, with main roads in thick red lines and secondary side roads in thin red lines. Black dot $=$ collecting locality of Bopopia parviflora gen. et sp. nov. Inset, an enlarged image of the vegetation of the area shows forest fragmentation by fire (from Gouvernement de la Nouvelle-Calédonie 2019). 
has no subtending bracteole, this latest being vestigial (Weber 2004; Haston \& De Craene 2007) except in Microchirita hamosa (R.Br.) Yin Z.Wang and Sinningia bulbosa (Ker Gawl.) Wiehler (Weber 1973, 2013). In Bopopia gen. nov. all front flowers are subtended by a distinct bract ( $\gamma$-bracteole) (Figs 4, 6). Its inflorescence is also strongly distinguished by the fact that one (or two) inflorescence(s) are born from the axil of the $\gamma$-bracteole of the first axis (Figs 2, 6), and not a solitary flower as classically described in the Gesneriaceae and more broadly the Lamiales (Weber 2013), with the exception of Penstemon serrulatus Menzies ex Sm. (Scrophulariaceae) which, however, develops only a single-branched cyme (Weber 1973). In Bopopia parviflora gen. et sp. nov., two axes develop from the axils of bracts $\alpha$ and $\beta$ of the first axis (Figs 2,6) into what we call the inflorescence sub-unit (ISU) (Fig. 2). One of these axes has an accessory origin. The material available already shows that, in addition to its molecular position in Negriinae, its inflorescence is unique, at least within the subtribe, and confirms that Bopopia gen. nov. deserves a special taxonomic rank. Further studies are needed, ideally with material at more advanced developmental stages, to define the variability and the complexity of this surprising inflorescence and to consider whether other taxonomic ranks need to be amended, including potentially the delimitation of the Gesneriaceae.

\section{Acknowledgments}

We warmly thank David Bruy and Marc Pignal for enthusiastic company in the field. The 'Our Planet Reviewed' - New Caledonia expedition (2016-2019) is a project of Muséum national d'histoire naturelle (MNHN) in partnership with Conservatoire d'espaces naturels (CEN) de Nouvelle-Calédonie. The 2017 Katalupaik expedition was funded mainly by the Gouvernement de la Nouvelle-Calédonie, Province Nord, and Office des Postes et Télécommunications (OPT), with in-kind support from AirCalin and Avis Nouvelle-Calédonie. The expedition operated under permit 60912-2001-2017/JJC issued by Direction du Développement Économique et de l'Environnement (DDEE) of Province Nord. Our Planet Reviewed/La Planète Revisitée is a global initiative founded in 2007 by MNHN and Pro-Natura International (PNI). Special thanks to Olivier Pascal for organizing the logistics of the 2017 expedition to Katalupaik. We are also grateful to Leila Zekraoui for her help with the laboratory work and Frédéric Legendre and Thomas Couvreur for their advice about phylogenetic analyses. Yves Caraglio contributed to a better characterization of the inflorescence and is greatly thanked. We would like to thank Anton Weber and an anonymous reviewer for their critical comments and questions which profoundly improved the original manuscript. Our thanks also go to the herbaria and teams of MPU, NOU and P.

\section{References}

AraújoA.O., Souza V.C. \& Perret M. 2010. Chautemsia calcicola : A new genus and species of Gloxinieae (Gesneriaceae) from Minas Gerais, Brazil. Taxon 59 (1): 203-208. https://doi.org/10.1002/tax.591019

Atkins H., Bramley G. \& Clark J.R. 2013. Current knowledge and future directions in the taxonomy of Cyrtandra (Gesneriaceae), with a new estimate of species numbers. Selbyana 31: 157-165. Available from: https://www.jstor.org/stable/24894287 [accessed 27 Jan. 2021].

Bebber D.P., Carine M.A., Wood J.R.I., Wortley A.H., Harris D.J., Prance G.T., Davidse G., Paige J., Pennington T.D., Robson N.K.B. \& Scotland R.W. 2010. Herbaria are a major frontier for species discovery. Proceedings of the National Academy of Sciences 107: 22169-22171.

https://doi.org/10.1073/pnas.1011841108

Birnbaum P., Ibanez T., Pouteau R., Vandrot H., Hequet V., Blanchard E. \& Jaffré T. 2015. Environmental correlates for tree occurrences, species distribution and richness on a high-elevation tropical island. $A o B$ PLANTS 7: plv075. https://doi.org/10.1093/aobpla/plv075

Castresana J. 2000. Selection of conserved blocks from multiple alignments for their use in phylogenetic analysis. Molecular Biology and Evolution 17 (4): 540-552.

https://doi.org/10.1093/oxfordjournals.molbev.a026334 
Clark J.L., Neill D.A., Weber A., Gruhn J.A. \& Katan T. 2010. Shuaria (Gesneriaceae), an arborescent new genus from the Cordillera del Cóndor and Amazonian Ecuador. Systematic Botany 35 (3): 662-674. https://doi.org/10.1600/036364410792495917

Cronk Q.C.B., Kiehn M., Wagner W.L. \& Smith J.F. 2005. Evolution of Cyrtandra (Gesneriaceae) in the Pacific Ocean: the origin of a supertramp clade. American Journal of Botany 92 (6): 1017-1024. https://doi.org/10.3732/ajb.92.6.1017

Doyle J.J., Davis J.I., Soreng R.J., Garvin D. \& Anderson M.J. 1992. Chloroplast DNA inversions and the origin of the grass family (Poaceae). Proceedings of the National Academy of Sciences 89 (16): 7722-7726. https://doi.org/10.1073/pnas.89.16.7722

Farris J.S., Källersjö M., Kluge A.G. \& Bult C. 1994. Testing significance of incongruence. Cladistics 10 (3): 315-319. https://doi.org/10.1111/j.1096-0031.1994.tb00181.x

Gâteblé G., Barrabé L., McPherson G., Munzinger J., Snow N. \& Swenson U. 2018. One new endemic plant species on average per month in New Caledonia, including eight more new species from Ile Art (Belep Islands), a major micro-hotspot in need of protection. Australian Systematic Botany 31: 448-480. https://doi.org/10.1071/SB18016

Gillett G.W. 1967. Coronanthera grandis (Gesneriaceae), a new species from the Solomon Islands. Journal of the Arnold Arboretum 48: 245-248. Available form: https://www.jstor.org/stable/43782348 [accessed 27 Jan. 2021].

Gouvernement de la Nouvelle-Calédonie. 2019. Explorateur cartographique Géorep.nc. Available from: https://arcg.is/KW41n [accessed 30 Aug. 2019].

Harris G.J. \& Harris M.W. 2001. Plant Identification Terminology: an Illustrated Glossary. $2^{\text {nd }}$ Edition. Spring Lake Publishing, Utah.

Haston E. \& De Craene L.P.R. 2007. Inflorescence and floral development in Streptocarpus and Saintpaulia (Gesneriaceae) with particular reference to the impact of bracteole suppression. Plant Systematic and Evolution 265: 13-25. https://doi.org/10.1007/s00606-006-0494-x

IUCN Standards and Petitions Committee. 2019. Guidelines for Using the IUCN Red List Categories and Criteria. Version 14. Prepared by the Standards and Petitions Subcommittee. Available from http://www.iucnredlist.org/documents/RedListGuidelines.pdf [accessed 27 Jan. 2021].

Jaffré T., Rigault F. \& Munzinger J. 2012. La végétation. In: Bonvallot J., Gay J.-C. \& Habert É. (eds) Atlas de la Nouvelle-Calédonie: 77-80. IRD-Congrès de la Nouvelle-Calédonie, Marseille-Nouméa.

Katoh K., Rozewicki J. \& Yamada K.D. 2017. MAFFT online service: multiple sequence alignment, interactive sequence choice and visualization. Briefings in Bioinformatics 20 (4): 1160-1166.

https://doi.org/10.1093/bib/bbx108

Lanfear R., Frandsen P.B., Wright A.M., Senfeld T. \& Calcott B. 2016. PartitionFinder 2: New methods for selecting partitioned models of evolution for molecular and morphological phylogenetic analyses. Molecular Biology and Evolution 34 (3): 772-773. https://doi.org/10.1093/molbev/msw260

Middleton D.J. \& Möller M. 2012. Tribounia, a new genus of Gesneriaceae from Thailand. Taxon 61 (6): 1286-1295. https://doi.org/10.1002/tax.616009

Morat P., Jaffré T. \& Veillon J.-M. 2001. The flora of New Caledonia's calcareous substrates. Adansonia, sér. 323 (1): 109-127. Available from: http://sciencepress.mnhn.fr/fr/periodiques/adansonia/23/1/laflore-des-substrats-calcaires-de-la-nouvelle-caledonie [accessed 27 Jan. 2021].

Morat P., Jaffré T., Tronchet F., Munzinger J., Pillon Y., Veillon J.-M. \& Chalopin M. 2012. Le référentiel taxonomique Florical et les caractéristiques de la flore vasculaire indigène de la Nouvelle-Calédonie. Adansonia, sér. 334 (2): 179-221. https://doi.org/10.5252/a2012n2a1 
Morrison D.A. 2006. Multiple sequence alignment for phylogenetic purposes. Australian Systematic Botany 19 (6): 479-539. https://doi.org/10.1071/SB06020

Munzinger J., Lowry II P.P., Callmander M.W. \& Buerki S. 2016. A taxonomic revision of the endemic New Caledonian genus Storthocalyx Baill. (Sapindaceae). Systematic Botany 41: 387-400. https://doi.org/10.1600/036364416X691902

Munzinger J., Pignal M. \& Bruy D. 2018 Flore \& Végétation du Katalupaik. In: Pascal O. (ed.) La Planète Revisitée, Nouvelle-Calédonie 2016-18, Volet «Forêt» 2017 en Province Nord, Rapport d'étape $N^{\circ}$ 1: 6-16. ProNatura/MNHN, Paris.

Munzinger J., Morat Ph., Jaffré T., Gâteblé G., Pillon Y., Rouhan G., Bruy D., Veillon J.-M. \& Chalopin M. 2020 [continuously updated]. FLORICAL: Checklist of the vascular indigenous flora of New Caledonia. Available from: http://publish.plantnet-project.org/project/florical [accessed 27 Jan. 2021].

Perret M., Chautems A., Araujo A.O. \& Salamin N. 2013. Temporal and spatial origin of Gesneriaceae in the New World inferred from plastid DNA sequences: Origin and Diversification of Gesneriaceae in the New World. Botanical Journal of the Linnean Society 171 (1): 61-79.

https://doi.org/10.1111/j.1095-8339.2012.01303.x

Posada D. \& Buckley T.R. 2004. Model selection and model averaging in phylogenetics: Advantages of Akaike information criterion and Bayesian approaches over likelihood ratio tests. Systematic Biology 53 (5): 793-808. https://doi.org/10.1080/10635150490522304

Roalson E.H. \& Roberts W.R. 2016. Distinct processes drive diversification in different clades of Gesneriaceae. Systematic Biology 65 (4): 662-684. https://doi.org/10.1093/sysbio/syw012

Ronquist F., Teslenko M., van der Mark P., Ayres D.L., Darling A., Höhna S., Larget B., Liu L., Suchard M.A. \& Huelsenbeck J.P. 2012. MrBayes 3.2: Efficient Bayesian phylogenetic inference and model choice across a large model space. Systematic Biology 61 (3): 539-542.

https://doi.org/10.1093/sysbio/sys029

Scarcelli N., Tostain S., Vigouroux Y., Agbangla C., Daïnou O. \& Pham J.L. 2006. Farmers' use of wild relative and sexual reproduction in a vegetatively propagated crop: The case of yam in Benin. Molecular Ecology 15: 2421-31. https://doi.org/10.1111/j.1365-294X.2006.02958.x

Sanger F., Nicklen S. \& Coulson A.R. 1977. DNA sequencing with chain-terminating inhibitors. Proceedings of the National Academy of Sciences 74 (12): 5463-5467.

https://doi.org/10.1073/pnas.74.12.5463

Serrano-Serrano M.L., Rolland J., Clark J.L., Salamin N. \& Perret M. 2017. Hummingbird pollination and the diversification of angiosperms: an old and successful association in Gesneriaceae. Proceedings of the Royal Society B: Biological Sciences 284 (1852): 20162816.

https://doi.org/10.1098/rspb.2016.2816

Stamatakis A. 2014. RAxML version 8: a tool for phylogenetic analysis and post-analysis of large phylogenies. Bioinformatics 30 (9): 1312-1313. https://doi.org/10.1093/bioinformatics/btu033

Suchard M.A., Lemey P., Baele G., Ayres D.L., Drummond A.J. \& Rambaut A. 2018 Bayesian phylogenetic and phylodynamic data integration using BEAST 1.10 Virus Evolution 4: vey016.

https://doi.org/10.1093/ve/vey016

Swofford D.L. 2002. PAUP*: Phylogenetic Analysis Using Parsimony (*and Other Methods). Version 4. Sinauer Associates, Sunderland, Massachusetts.

Taberlet P., Gielly L., Pautou G. \& Bouvet J. 1991. Universal primers for amplification of three noncoding regions of chloroplast DNA. Plant Molecular Biology 17 (5): 1105-1109.

https://doi.org/10.1007/BF00037152 
Thiers B. continuously updated. Index Herbariorum: A Global Directory of Public Herbaria and Associated Staff. New York Botanical Garden's Virtual Herbarium.

Available from: http://sweetgum.nybg.org/ih/ [accessed 27 Jan. 2021].

Wagstaff S.J. \& Garnock-Jones P.J. 1998. Evolution and biogeography of the Hebe complex (Scrophulariaceae) inferred from ITS sequences. New Zealand Journal of Botany 36: 425-437.

https://doi.org/10.1080/0028825X.1998.9512581

Weber A. 1973. Die Struktur der paarblütigen Partialfloreszenzen der Gesneriaceen und bestimmter Scrophulariaceen. Beiträge zur Biologie der Pflanzen 49: 429-460.

Weber A. 1982. Evolution and radiation of the Pair-Flowered Cyme in Gesneriaceae. Australian Systematic Botany Society Newsletter 30: 23-41.

Weber A. 1995. Developmental aspects of the Pair-Flowered Cyme of Gesneriaceae. Gesneriana 1: $18-28$.

Weber A. 2004. Gesneriaceae. In: Kadereit J. (ed.) The Families and Genera of Vascular Plants. Vol. 7. Flowering Plants. Dicotyledons. Lamiales (Except Acanthaceae Including Avicenniaceae): 63-158. Springer, Berlin. Available from https://link.springer.com/chapter/10.1007/978-3-642-18617-2_8 [accessed 11 Feb. 2021].

Weber A. 2013. Pair-flowered cymes in the Lamiales: structure, distribution and origin. Annals of Botany 112 (8): 1577-1595. https://doi.org/10.1093/aob/mct156

Weber A., Clark J.L. \& Möller M. 2013. A new formal classification of Gesneriaceae. Selbyana 31 (2): 68-94. Available from: https://www.jstor.org/stable/24894283 [accessed 27 Jan. 2021].

Wei Y.-G., Wen F., Chen W.-H., Shui Y.-M. \& Möller M. 2010. Litostigma, a new genus from China: A morphological link between basal and derived didymocarpoid Gesneriaceae. Edinburgh Journal of Botany 67: 161-184. https://doi.org/10.1017/S0960428609990291

White T.J., Bruns T., Lee S.J.W.T. \& Taylor J.L. 1990. Amplification and direct sequencing of fungal ribosomal RNA genes for phylogenetics. PCR Protocols: a Guide to Methods and Applications 18 (1): 315-322. https://doi.org/10.1016/b978-0-12-372180-8.50042-1

Woo V.L. 2007. Evolution, Biogeography and Taxonomy of the Southwest Pacific Tribe Coronanthereae (Gesneriaceae). $\mathrm{PhD}$ thesis, Victoria University of Wellington, New Zealand.

Woo V.L., Funke M.M., Smith J.F., Lockhart P.J. \& Garnock-Jones P.J. 2011. New World origins of Southwest Pacific Gesneriaceae: Multiple movements across and within the South Pacific. International Journal of Plant Sciences 172 (3): 434-457. https://doi.org/10.1086/658183

Manuscript received: 4 March 2020

Manuscript accepted: 26 November 2020

Published on: 1 March 2021

Topic editor: Frederik Leliaert

Desk editor: Radka Rosenbaumová

Printed versions of all papers are also deposited in the libraries of the institutes that are members of the EJT consortium: Muséum national d'histoire naturelle, Paris, France; Meise Botanic Garden, Belgium; Royal Museum for Central Africa, Tervuren, Belgium; Royal Belgian Institute of Natural Sciences, Brussels, Belgium; Natural History Museum of Denmark, Copenhagen, Denmark; Naturalis Biodiversity Center, Leiden, the Netherlands; Museo Nacional de Ciencias Naturales-CSIC, Madrid, Spain; Real Jardín Botánico de Madrid CSIC, Spain; Zoological Research Museum Alexander Koenig, Bonn, Germany; National Museum, Prague, Czech Republic. 


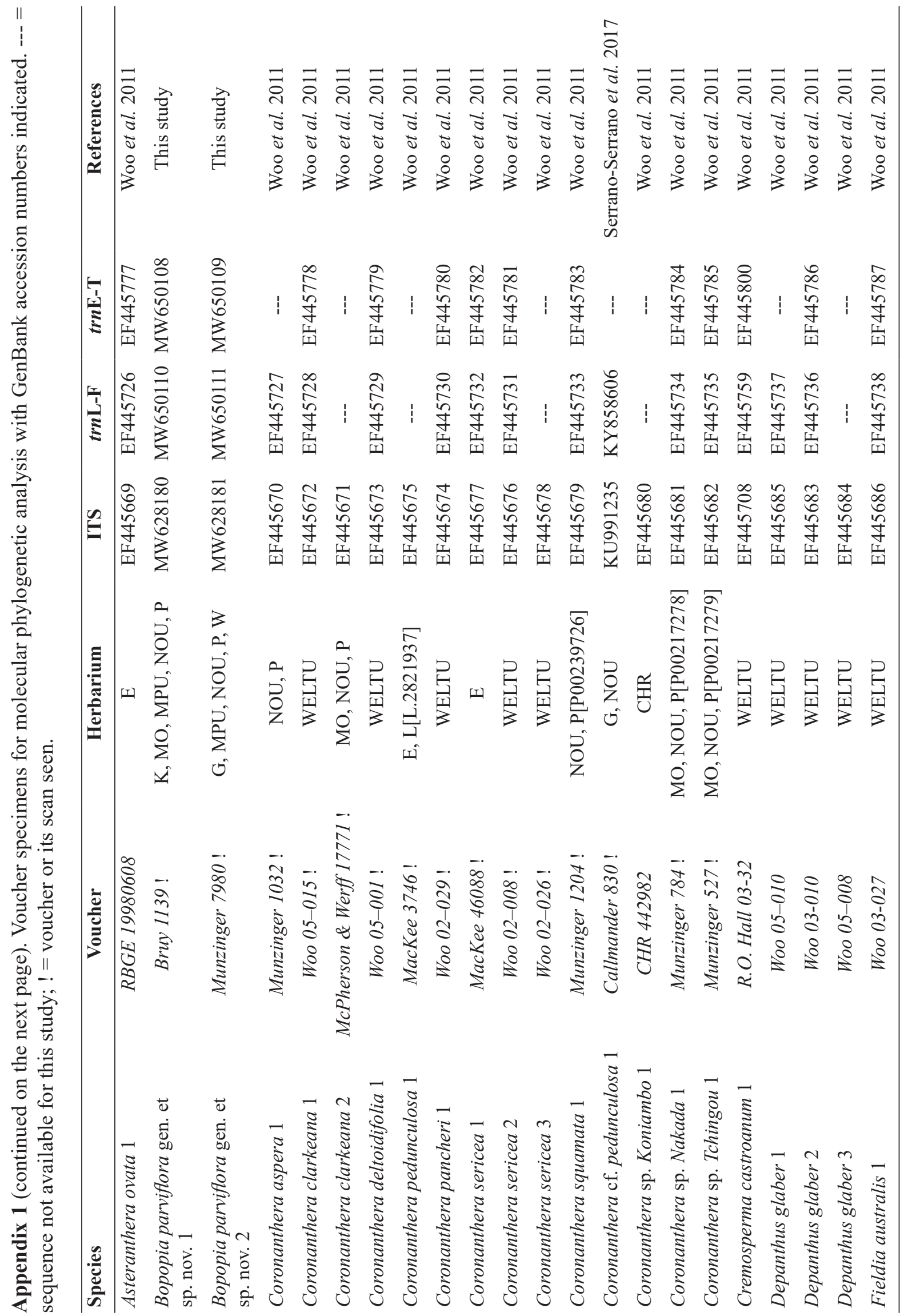




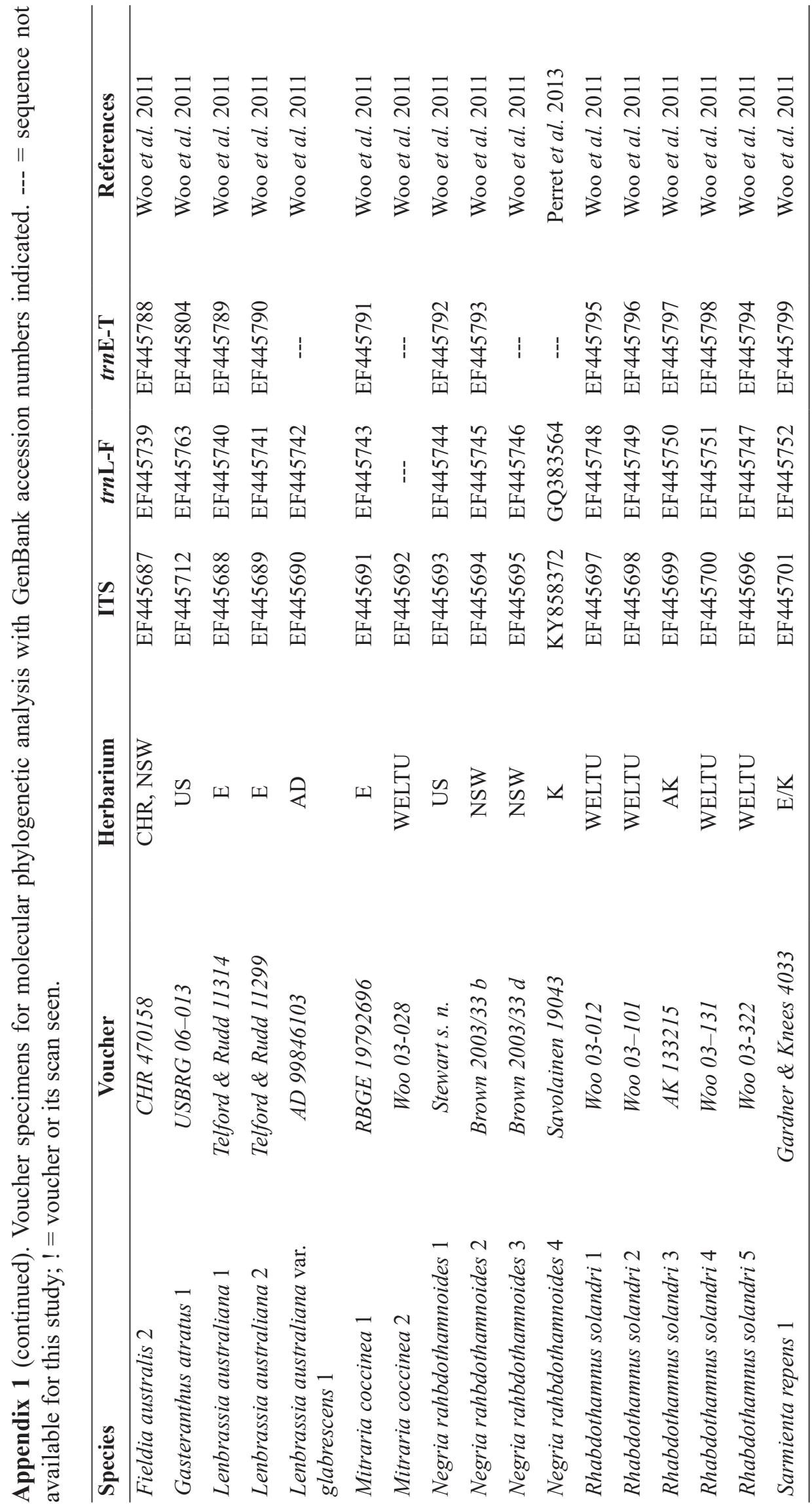

